\title{
Task and Forced Instructional Strategy: Instructional Strategy Based on Character and Culture of Indonesia Nation
}

\author{
Leonard \\ Indraprasta PGRI University \\ Jl. Nangka No. 58c Tanjung Barat, Jakarta, Indonesia
}

\begin{abstract}
$\begin{array}{ll} & \text { Abstract } \\ \text { Received: } & \text { March 31, } 2018 \quad \text { The application of instructional strategy must be considered to the }\end{array}$ Revised: April 3, 2018 characteristics and students' culture to get an optimal learning result. The Accepted: April 3, $2018 \quad$ Indonesian character's to be based on this strategy isn't finish the task well if there is no compulsion or punishment. This character to be a background of purpose task and forced instructional strategy. This strategy emphasized a routine task and well plan for the students, notice the deadline for finishing the task and the punishment if the task doesn't finish well. This strategy can be the alternative strategy to increase learning quality, especially to develop the student's awareness about how the study is the important things for themselves.
\end{abstract}

Keywords: instructional strategy, task and forced, Indonesian character

(*) Corresponding Author: $\quad$ E-mail: leonard@unindra.ac.id - 081382939050

How to Cite: Leonard. (2018). Task and forced instructional strategy: Instructional strategy based on character and culture of Indonesia nation. Formatif: Jurnal Ilmiah Pendidikan MIPA, 8 (1): 51-56. http://dx.doi.org/10.30998/formatif.v8i1.2408

We can say that learning process in the classroom is successful if students can control knowledge and use it if necessary, and build the student's awareness of the important knowledge they have been received. Beside it, the learning process must be fun, full of friendly atmosphere, but the essentials of student's obligation to understand the material from the teacher must exist. The ability to designing this atmosphere must be controlled by the teacher, so the aim of the learning can be reached. But the fact is, too many teachers can't design the fun atmosphere, they preference learning materials towards the learning goals as the base of learning process they have done (Leonard, 2015). This needs to be fixed and attempts to certain efforts, so the learning quality can be increased. Suparman (2012) said that the effort to increase the quality of learning process can be done by doing the systemic activity to learning development using learning technology like (a) learning identified, (b) learning development, and (c) learning evaluation.

Koehler \& Mishfra (2005) said learning by design appears to be an effective instructional technique to develop deeper understandings of the complex web of relationships between content, pedagogy and technology and the contexts in which they function. It shows that designing the learning process absolutely doing by the teacher, with the purpose to increase the learning quality. But, nowadays were often still found of learning is taking place is inexpensive, but even without the good plan. The learning process can run well, if the student gets the accommodation learning about their personality aspects, such as character and their culture. This research has proven that a culturally responsive pedagogy recognizes cultural knowledge, prior experiences and values of the 
Formatif: Jurnal Ilmiah Pendidikan MIPA

Vol. 8, No. 1, April 2018, pp. 51-56

p-ISSN: 2088-351X

e-ISSN: $2502-5457$

DOI: http://dx.doi.org/10.30998/formatif.v8i1.2408

community concerned. The learner's context and experience play a central role in the learning process (Thanabalan, Siraj, \& Alias, 2015). This situation can be implied the teacher's obligation to develop learning based on community and the student's culture they have taught. Teachers should be exposed to the indigenous community and their cultural practices so that effective instruction can be developed to match the needs of the indigenous learners (Thanabalan, Siraj, \& Alias, 2015).

As a big nation, Indonesia has a long story and the unique culture can be analyzed and used for learning development. There are too many cultures and characters the Indonesian, it can from the positive or negatives sides. But, the effect of the colonial invasion for 350 years and the invasion of Japan for 3,5 years was made to many differences for Indonesian. In spite of the struggle, Indonesian are the people whose never give up, and have the good spirit of fight, especially in the invasion era. On the contrary, the negative character appear as a result of the invasion is there is the weak of mentality generation, the weak character (Husaini, 2010), Less of initiatives, tended not to make a work if there is not monitored or being forced by the leader, doing something because of forced by the punishment or other situation or the other reason.

Because of the character, some of Indonesian whoever must be given the task to work and forced to do something and even punishment if don't, so the writer tries to develop the instructional strategy based on the background. The strategy's name given is task and force strategy. This strategy tries to take the weakness things some of Indonesian, so the learning process can be run effectively, even theoretically, it contrary to the general learning theory. Shell et al. (2010) write In the ULM (Unified Learning Model), all effective classroom practice is anchored in the three principles of learning: 1. Learning is a product of working memory allocation. 2 . Working memory's capacity for allocation is affected by prior knowledge. 3. Working memory allocation is directed by motivation. The effectively learning with the specific principles will be difficult to reach if using the conventional instructional strategy, because in Indonesia, especially in the university, the students need to be directed step by step with the rules and a clear target. The process of the assignment and compulsion did correctly so can get the learning process philosophy including force - forced - usual - usually - culture - civilized nations.

Cohen (2005) said an instructional strategy, also known as an instructional method, is based on a decision about how information should best be presented or taught. Lohr (Cohen, 2005) adding, it is derived from the analysis of learner, task, and context that preceded it. Learning isn't only how to deliver materials, but the strategy is needed to make sure the learning process is effective and efficient to deliver the materials. Hopkins (2007) explained Teaching is more than just presenting material; it is about infusing curriculum content with appropriate instructional strategies that are selected in order to achieve the learning goals the teacher has for her/his students. Instructional strategy task and force hopefully can increase the student's awareness about how important learning is and finally them aware that study is the compulsory activity they have to do, the aim is to develop themselves. Shell et al. (2010) said the five rules of learning provide specific guidance for enacting the three principles. These say that effective instruction must do the following: 1 . direct student attention to the desired knowledge to be learned. Help students focus attention on relevant materials and avoid distractions through the learning environment, instructional materials, and connection to students' prior knowledge. 2. Provide necessary repetition. Provide multiple exposures to the knowledge to be learned and opportunities for recall and practice. 3. Facilitate connections. Provide ways for students to connect what they are learning to what they have previously learned in the class, what they have learned in other classes, and their other prior knowledge. Help them to construct meaningful connections between what they know and what they are learning. 4. Provide a learning 
Formatif: Jurnal Ilmiah Pendidikan MIPA

Vol. 8, No. 1, April 2018, pp. 51-56

p-ISSN: 2088-351X

e-ISSN: 2502-5457

DOI: http://dx.doi.org/10.30998/formatif.v8i1.2408

environment that facilitates motivation. Recognize that learning can be difficult and provide support for maintaining students' effort. 5. Remember that learning is learning. Directing attention, providing repetition, facilitating connections, and providing motivation are the parts of the good instruction. There are no shortcuts; good teaching does not follow fads.

Task and force strategy can be implemented by simultaneously with the model or other learning methods. We can say that this instructional strategy as the extra activity beside the other activity has been planned. The point is, this instructional strategy emphasized the comprehensive planning related to assigned tasks to the students, complete with the punishment or threat will be given to the student if they don't do the task well. The writer experience in applying this strategy is:

1. Students were asked to buy an education and learning book, then read and make the summary of the book. The students have a week only to finish the assignment and make the summary with their handwriting. Next, students change their book with their classmates, then repeated read and make the summary for a week.

2. Students were made familiar to given task in every meeting of lecturer, it must be finished a day before the next meeting. This assignment usually related to the material is given. In the writer case, on research methodology subject, usually, the task downloads the research articles, carried out the study directly to do the problems analyze, doing the objective of the interview limited to the teachers or students, collect the important theory or sentences about the research, and so on.

3. Every question from the students about the materials, will be the private assignment or group, and must be finished on the same day, and must be reported through the message on WhatsApp application.

4. There is the punishment will be given to the student if they don't do the assignment well and on time, it's like the reduction of the score, the other assignment and doesn't pass the research methodology subject.

Technically, so many challenges and obstacles in applying of this strategy. So many complain from the students, especially from the student who doesn't usually do so many assignments in a few time. But, this is what is being restored. Laziness characters, give up, stunned with a task, do with the heavy heart and so on are unloaded for replacing with the new habit to read and doing the assignment at the right time. In the beginning, so many students complain, but in the end, they give an appreciation, because, with the little force, they can be able to face the challenges in the future, especially to the design of research in the final stage of the lecture. The keywords must be the notice in applying task and force strategy is there is the regular and planned assignment had been the readiness by the teacher according to the subject or material, and the deadline of a task, also the punishment if the task can't be done well.

Yau, Cheng, \& Ho (2015) said there are extensive educational literature which is related to the student's motivation for learning and the instructional strategies affecting the student's motivation (Keller, 1984; 1987; 2010; Oliver \& Reeves, 1996; etc.). in generally, to provide the motivation, could do by some ways, such as students are given the gift by the teacher, given the appreciation, and even given the task and force. In the beginning, maybe would be a lot of complaint and contrariety, but if refer on the theory of learning by Thorndike about the habituation, so this strategy can be the way to educate the students. (Shih, Liu, \& Sanchez, 2013) In the past, school instruction was focused on course designs and teachers' instructional strategies, which was believed to suffice for promoting effective learning. Through time, we have come to an understanding that teaching quality is deeply affected by student's characteristics, the teacher's teaching styles, and teaching environment (Keefe, 1987). 


\section{Formatif: Jurnal Ilmiah Pendidikan MIPA}

Vol. 8, No. 1, April 2018, pp. 51-56

p-ISSN: 2088-351X

e-ISSN: 2502-5457

DOI: http://dx.doi.org/10.30998/formatif.v8i1.2408

Task and force strategy hopefully can be the extra treatment for the students to increase the learning quality. Notice that this strategy must be given compatible with student's characteristics who taught, so can give the better influence. In this short paper, the target audience is the students in the college, who are treated with andragogy. This should be of concern and should be adjusted if it should be used on students at the basic level, like elementary school, junior high school, and senior high school, who are treated pedagogically.

\section{REFERENCES}

Cha, H. J., \& Ahn, M. L. (2014). Development of design guidelines for tools to promote differentiated instruction in classroom teaching. Asia Pacific Education Review, 15, 511-523. http://doi.org/10.1007/s12564-014-9337-6

Cohen, D. E. S. (2005). The Online Resources Selection Instructional Design Script (ORSIDS). Published Dissertation. Graduate School of Computer and Information Sciences, Nova Southeastern University.

Hopkins, D. (2007). Every School a Great School-Realizing the Potential of System Leadership. England: Open University Press.

Husaini, A. (2010). Pendidikan Karakter: Penting, Tapi Tidak Cukup! Paper disampaikan dalam Diskusi Sabtuan INSISTS, 12 Juni 2010. Online. http://blog.umy.ac.id/saladinalbany/files/2012/10/PENDIDIKAN.pdf

Koehler, M. J., \& Mishra, P. (2005). What happens when teachers design educational technology? The development of Technological Pedagogical Content Knowledge. Journal of Educational Computing Research, 32(2), 131-152. http://doi.org/10.2190/0EW7-01WB-BKHL-QDYV

Keller, J. M. (1984). The use of the ARCS model of motivation in teacher training. In K. S. A. J. Trott (Ed.), Aspects of educational technology volume XVII: Staff development and career updating. London: Kogan Page.

Keller, J. M. (1987). Development and use of the ARCS model of instructional design. Journal of Instructional Development, 10(3), 2-10.

Keller, J. M.(2010). Motivational Design for Learning and Performance. Springer.

Leonard, L. (2015). Kompetensi tenaga pendidik di Indonesia: Analisis dampak rendahnya kualitas SDM guru dan solusi perbaikannya. Jurnal Formatif, 5(3), 192-201. Retrieved

from http://journal.lppmunindra.ac.id/index.php/Formatif/article/view/643/569

Oliver, R., \& Reeves, T. C. (1996). Dimensions of effective interactive learning with telematics for distance education. Educational Technology Research and Development, 44(4), 45-56.

Roberts, T. S. (2005). Computer-Supported Collaborative Learning in Higher Education. Australia: Central Queensland University. http://doi.org/10.1108/eb016555

Shell, D. F., Brooks, D. W., Trainin, G., Wilson, K. M., Kauffman, D. F., \& Herr, L. M. (2010). The Unified Learning Model. New York: Springer. http://doi.org/10.1007/978-90-481-3215-7

Shih, Y. D., Liu, Y.-C., \& Sanchez, C. (2013). Online learning Style preferences: An analysis on Taiwanese and USA learners. TOJET: The Turkish Online Journal of Educational Technology, 12(4), 140-152.

Sims, R. R., \& Sims, S. J. (1995). The Importance of Learning Styles. (R. R. Sims \& S. J. Sims, Eds.). London: Greenwood Press. 
Formatif: Jurnal Ilmiah Pendidikan MIPA

Vol. 8, No. 1, April 2018, pp. 51-56

p-ISSN: 2088-351X

e-ISSN: 2502-5457

DOI: http://dx.doi.org/10.30998/formatif.v8i1.2408

Suparman, A. (2014). Desain Instruksional Modern: Panduan Para Pengajar dan Inovator Pendidikan. Jakarta: Erlangga.

Thanabalan, T. V., Siraj, S., \& Alias, N. (2015). Evaluation of a digital story pedagogical module for the indigenous learners using the stake countenance model. TOJET: The Turkish Online Journal of Educational Technology, 14(2), 63-72.

Yau, H. K., Cheng, A. L. F., \& Ho, M. W. M. (2015). Identify the motivational factors to affect the higher education students to learn using technology. TOJET: The Turkish Online Journal of Educational Technology, 14(2), 89-100. 
Formatif: Jurnal Ilmiah Pendidikan MIPA

Vol. 8, No. 1, April 2018, pp. 51-56

p-ISSN: 2088-351X

e-ISSN: 2502-5457

DOI: http://dx.doi.org/10.30998/formatif.v8i1.2408 